\title{
Research on the Mode of Training Business Administration Talents
}

\author{
Haifeng Liao \\ Dean's Office, Guangdong University of Science \& Technology, Dongguan China \\ E-mail: chaoxiaojie123@163.com
}

Keywords: business management; talent training; social needs; teaching characteristics

\begin{abstract}
In the relevant instructions issued by the Ministry of Education of the People's Republic of China in 2012, it can be found that the business administration profession has become a key target in the professional development of Chinese universities. The business administration program aims to develop a comprehensive talent for the development and management of all types of enterprises for the country and society. Such talents not only need to have professional personal knowledge, but also need to have a certain sense of innovation, be able to adjust their own state according to different environments, and create maximum value for enterprises and society. Based on the specific needs of society, this paper analyzes the current teaching characteristics of colleges and universities, and puts forward some suggestions for the curriculum system and teaching methods. It hopes to make some contributions to the development of business administration in China.
\end{abstract}

\section{Introduction}

As early as March 10, 2016, China’s Minister of Education Yuan Guiren had raised his views on higher education in China at a major meeting. The overall opinion is that he believes that China's higher education mainly trains academic talents, and few colleges and universities can achieve a more advanced student training model. That is to say, many college students are "written talents" who can only theoretically and will not actually operate. ${ }^{[1]}$ In addition, the curriculum between the school and the school is relatively close, the training model is very similar, and does not focus on innovation. This article is based on the fact that it analyzes the training mode of colleges and universities in business management under the current educational background, proposes corresponding reform measures, tries to promote the development of China's business administration major, and alleviates the reality that China's business management professionals are not in line with market demand. contradiction.

\section{Problems in the training of business management talents}

At present, there are many problems in the mode of training business management talents in China. Most of these problems stem from the irregularity of school curriculum, and some of them are influenced by social reality. Specifically divided into the following aspects:

\subsection{The concept of running a school is out of touch with reality}

In the current management of many colleges and universities, the concept of running a lot of schools is very unrealistic. The main reason is that colleges and universities have not formed a distinctive school-running model, which is based on the common teaching methods used in the past. Many business administration students enter the school and think that they must be a manager after graduation. In fact, such an idea is very wrong, because a real manager needs to go through a lot of practical exercises to achieve. However, many schools did not explain this when students entered the school, which led to many inaccurate positioning of themselves. The school did not pay attention to practical drills, blindly pursued the knowledge in textbooks, and ignored the development of reality.

\subsection{The course setting is unreasonable}

Business administration itself is a first-level discipline, and there are many secondary disciplines, such as human resources, accounting, and marketing. However, in the actual teaching process, because 
there are many time conflicts in the courses of business administration, accounting, human resources, marketing, etc., this leads to the failure of business administration students to learn professionally like the previous professional students. knowledge. According to the survey, many courses for business administration students are very superficial. Their courses are not as professional as accounting and professional, nor are they as practical as marketing and other majors. ${ }^{[2]}$ The final result is business administration. The students are unqualified in theory and practice, and finally unable to adapt to the fast pace of society and the high demand for work. It is reported that the former business administration students have to study more than 40 courses in the four years of the university, totaling more than 3,500 class hours. It can be seen that the scope of business administration professional courses is extremely wide and lacks pertinence, and students have no time to participate in extracurricular practice and lose the opportunity for practical operation.

\subsection{Students have poor practical ability}

After graduation, students majoring in business administration generally want to enter the work of the enterprise. The situation of different enterprises is very different, so students must have sufficient ability to cope with these situations in order to gain a place in the workplace. However, as far as the domestic business management students are concerned, they rarely have the opportunity to contact the actual enterprises for training. On the one hand, the school theory courses are relatively full, there is no time for practical exercises, and on the other hand, because the schools are not set up. In the teaching process, students have no way to participate in the management of the company. After recruiting business management students, many companies need to cultivate themselves from scratch, because many of the students' learning in the school cannot be used in actual work. What is even more shocking is that many college and university business management students are not very skilled in the operation of the most basic office software after graduation. This is a big loss for the enterprise. With the increase of social competitiveness, the competitiveness of such business administration students is becoming weaker and weaker. Their disadvantages are becoming more and more obvious when they apply for a job. It is gratifying to note that there are still a small number of colleges and universities that will carry out practical courses in business administration on campus, trying to make up for such a deficiency. In the process of business administration, there are few internships and practice trainings in schools, and the lack of practical teaching materials has led to the lack of opportunities for students to contact the society and the lack of professional practical ability, which hinders the cultivation of business management talents. At present, the domestic industrial and commercial drawings below Figure 1 and Figure 2 are screenshots of the practical courses for business administration students on campus.
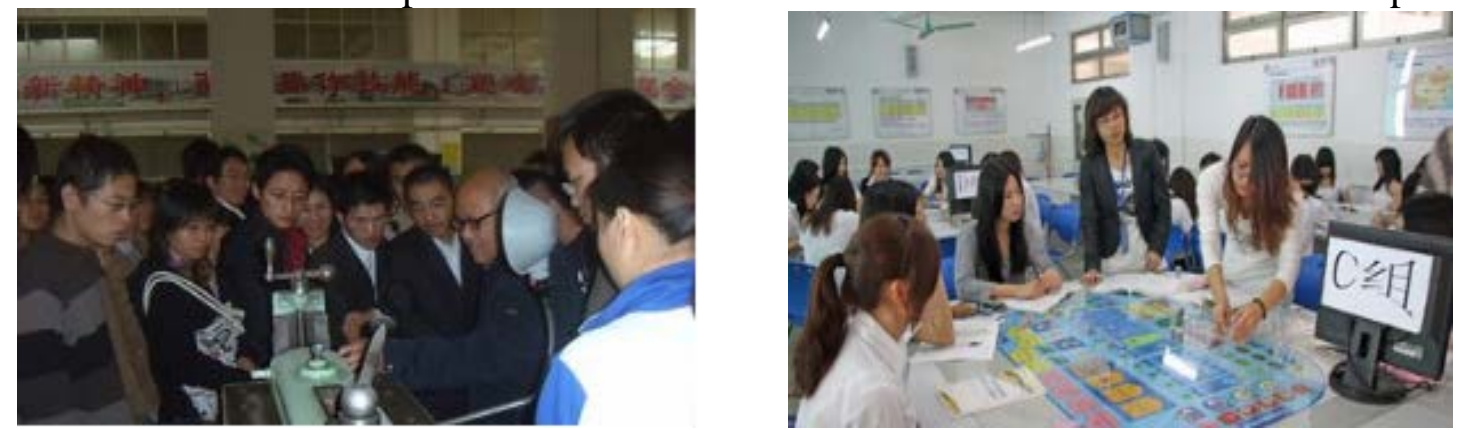

Figure 1 Business Administration Student Practice Courses

\section{Scientific improvement measures for the training of business management talents}

\subsection{The government vigorously implements a new strategy for training business management talents}

Higher vocational colleges are an important channel for the transfer of talents to our society and enterprises. Relevant government departments should vigorously implement relevant reform measures. At present, the cultivation of business administration in colleges and universities in China has exposed problems, so the education department of our country should solve this problem as soon as possible. 
The government should invest more energy in education and encourage universities to cooperate with enterprises, governments and society to achieve multi-directional cooperation and win-win. In addition, the government must also conduct certain supervision over school-enterprise cooperation, commend the good school-enterprise cooperation cases, encourage students in the school to go out of the school, enter the enterprise, and exercise themselves. At the same time, for the preferential projects between school-enterprise cooperation, the government can also provide certain assistance to ensure the smooth cooperation between the school and enterprise, so that colleges and universities are full of confidence in such a student training model. ${ }^{[3]}$ The cultivation method of business management talents in higher vocational colleges is very important, because it is directly related to the quality of management talents recruited behind the enterprise, which indirectly affects the future development of the enterprise and has a very significant impact on the economic development of our society. All in all, increase the intensity of enterprises and schools to achieve talent training models, and promote the development of business management talents.

\subsection{Expand the influence between industries}

The so-called expansion of the impact between the industry is mainly to enhance the links between schools, governments and enterprises. Society is a process of creating many connections between multiple groups. The relationship between schools, governments, and enterprises can be infinitely enhanced and can produce a series of unexpected effects. Enterprises can provide a platform for practical drills for schools to help students of business administration majors grow up as soon as possible. Schools can provide theoretical training for enterprises and enhance information services of enterprises. In addition, the government can supervise such exchanges between schools and enterprises, and timely review and remind them of non-compliant operations to ensure the normal and orderly development of society, and students receive education in a safe legal environment. Schools and enterprises are two entities that cannot be completely separated. The government must rationally exert all its rights and expand the influence between industries to make social development faster and more efficient.

\subsection{Improve the qualification requirements for school-enterprise cooperation}

The result of school-enterprise cooperation will have a great impact on schools, enterprises and students. For students, it is the acquisition of personal ability. For the school, it is the achievement of student training. For enterprises, it is the consumption of human and financial resources. Therefore, for the enterprise qualification review of school-enterprise cooperation, the government should put forward higher requirements, the school should also review the enterprise, and the enterprise should also judge the school. ${ }^{[4]}$ Take the school-to-business review, in addition to paying attention to the job responsibilities, accommodation and working environment that students are going to have internships, they must also make a specific understanding of the company's training requirements and objectives to ensure students. The effectiveness of the internship does not waste the time and effort of the company and the students.

\subsection{Develop a sincere school-enterprise cooperation model}

Because of the social experience and theoretical time experience of the students in the school, many companies are irresponsible in dealing with the interns entering the school. Therefore, school-enterprise cooperation must be sincere and reliable. When communicating with enterprises, schools should pay attention to methods and methods, not only to educate students, but also to maintain a sincere and friendly attitude towards the company and to maximize their satisfaction with the interns. In fact, if companies can change their previous ideas and accept interns as much as possible, they will set a good benchmark in the industry, so that more high-quality enterprises can be integrated into the new talent training model of Taoist-enterprise cooperation. Development has opened up a new path to create a promising path for high-skilled business management professionals. 


\section{Conclusion}

There are certain problems in the current business management talent model in China, but as long as the current education model is changed according to the requirements of the society and enterprises for business management talents, it will certainly achieve better results. The new model of school-enterprise cooperation is the biggest change in the cultivation of business management talents. I hope that in the near future, we can see that China's business management personnel training model has made great progress.

\section{References}

[1] Kong Weiwei. Business Administration Major: Management Creates Value [J]. Exam and Admissions, 2016.Z1.

[2] Xu Zhijie.Research on Teaching Method Reform of Business Administration Major Courses[J]. Time Education,2016.11.

[3] Wang Yihong. Research on Employment-oriented Applied Business Administration Practice Teaching[J]. Human Resources Management,2016.5.

[4] Wang Xinyu. Analysis and Thinking of the Status Quo of Business Administration[J]. Management Manager,2016.13. 